\title{
THE ELMA E. KOCH MEMORIAL FUND
}

On June 5, I957, Rutgers University awarded posthumously to Elma E. Koch the degree of Master of Science. Mrs. Koch, a graduate of Smith, had successfully completed all the requirements for the degree in psychology: her thesis, entitled Mirror-Tracing Ability as a Function of Personality: a Perceptual Approach, reported the results of a series of experiments designed to show the relation between learning ability and personality. She had been elected to Psi Chi in the second year of her studies. Her sudden death in an automobile accident, two days before Commencement, put an ironic end to her career, just then beginning, before she had had time to go beyond the preparation for it.

Her many friends, both in New Brunswick and in Schenectady, decided to create as her memorial a fund to purchase books in psychology for the University Library, whose facilities she had used constantly and appreciatively. Sixteen volumes, selected by the members of the Psychology Department, have been purchased for the regular Rutgers University Library book collections, and the fund is not yet exhausted. Shelved in the $P_{\text {sychology Office on in- }}$ definite loan from the Library, they have already been much used with gratitude and affection. The donors include psychology students who knew Mrs. Koch, professors who taught her, staff members who helped her with the red tape of acquiring a degree, and friends who served as guinea pigs in the mirror-tracing and similar experiments.

The titles of the books, each of which bears the Rutgers University Library bookplate with the inscription "In memory of Elma E. Koch, M.S. 1957," follow: Allport, Theories of Perception and the Concept of Structure; Barlow, Tables; Buros, Mental Measurements Yearbook; Dollard and Miller, Personality and Psychotherapy; Grings, Laboratory Instrumentation in Psychology; Helson, Theoretical Foundations of Psychology; Hilgard, Theories of Learning; Lindquist, Design and Analysis of Experiments in Psychology and Education; Lindzey, Handbook of Social Psychology; Marx, Psychological Theory; Ross and Van den Haag, The Fabric of Society; Osgood, Method and Theory in Experimental Psychology; Siegel, Nonparametric Statistics for the Behavioral Sciences; Skinner, Behavior of Organisms: an Experimental Analysis; Stevens, Handbook of Experimental Psychology; Woodworth and Schlosberg, Experimental Psychology.

Lillian B. Goodhart 